CIVICS EDUCATION AND SOCIAL SCIENSE JOURNAL(CESSJ)

Volume 2 Nomor 1 Bulan Juni 2020

\title{
PERAN KELUARGA DALAM MENANAMKAN SIKAP BELA NEGARA PADA REMAJA
}

\author{
Ika Murtiningsih, M.Pd \\ Dosen PPKn, Universitas Veteran Bantara Sukoharjo \\ Email: ika.murtyy@gmail.com
}

\begin{abstract}
Abstrak
Peran keluarga sangat dibutuhkan dalam menanamkan sikap bela negara pada remaja. Keluarga merupakan sumber pendidikan pertama dan utama dalam menumbuhkan sikap mencintai tanah air, sadar berbangsa dan bernegara, yakin adanya Pancasila sebagai ideologi negara, rasa rela berkorban untuk bangsa dan negara Indonesia, dan memiliki kemampuan awal bela negara. Peran keluarga dalam menanamkan sikap bela negara masih kurang ditandai dengan: 1) keluarga dan remaja kurang menyukai produk dalam negeri, 2) tidak hafalnya lagu nasional, 3) remaja tidak memakai atribut lengkap saat mengikuti upacara, 4) seringnya remaja bolos sekolah, dan 5) belum melestarikan budaya belajar dengan rajin. Peran keluarga dalam menanamkan sikap bela negara telah terlaksana secara optimal, namun hanya perlu aktualisasi secara mendalam dan berkelanjutan.
\end{abstract}

Kata Kunci: Keluarga, Bela Negara, Remaja

\begin{abstract}
$\underline{\text { Abstract }}$
Family roles are much needed in instilling state defense in teenagers. The family is the first and foremost source of education in cultivating a homeland loving attitude, nation conscious and state, believed to be a state ideology, $\underline{\text { a sense }} \underline{\text { of }} \underline{\text { sacrifice }} \underline{\text { for Indonesia's }}$ nation and state, and have early national defense capabilities. The role of family in instilling state defense is still less characterized by: 1) families and adolescents dislike domestic products, 2) not memorize the national anthem, 3) teenagers do not use the full attributes when attending the ceremony, 4) frequent teen skip school, and 5) have not preserved the culture of learning diligently. The role of family in state defense attitudes has been carried out optimally, but it only needs to be deeply and sustainably actualized.
\end{abstract}

Keywords: Family, State Defense, Teenager

JORNAL PROGDI PPKn, FKIP UNIVET BANTARA SUKOHARJO BEKERJA SAMA DENGAN ASSOSIASI PROFESI PENDIDIKAN PANCASILA DAN KEWARGANEGARAAN (AP3KNI) JAWA TENGAH 
CIVICS EDUCATION AND SOCIAL SCIENSE JOURNAL(CESSJ)

Volume 2 Nomor 1 Bulan Juni 2020

\section{PENDAHULUAN}

Keluarga merupakan forum pendidikan karakter yang pertama dan utama bagi anak terkhusus remaja. Menciptakan karakter yang kuat pada remaja dalam keluarga, diperlukan terciptanya suasana keluarga yang harmonis dan dinamis. Hal tersebut dapat dilakukan dengan terjalinnya koordinasi dan komunikasi dua arah yang kuat antara remaja dan keluarga.

Keluarga memiliki pengaruh dalam menanamkan sikap bela negara pada remaja. Sikap bela negara dibutuhkan agar setiap warga negara mempunyai sikap mencintai tanah air, sadar berbangsa dan bernegara, yakin adanya Pancasila sebagai ideologi negara, rasa rela berkorban untuk bangsa dan negara Indonesia, dan memiliki kemampuan awal bela negara. Kelima nilai-nilai bela negara tersebut harus ditanamkan pada remaja melalui keluarga, karena keluarga merupakan orang terdekat dengan remaja.

Penanaman sikap bela negara harus dilakukan sejak dini, hal ini dilakukan agar anak memahami pentingnya sikap bela negara dan kehidupan berbangsa dan bernegara. Bela negara dapat dilakukan dengan cara belajar tekun, menjagakan keamanan di lingkungan masyarakat ataupun lingkungan sekolah dari ancaman yang dapat membahayakan kehidupan berbangsa dan bernegara, tidak membuang sampah sembarangan menghormati bendera merah putih dan lagu kebangsaan, serta menolak campur tangan pihak asing terhadap kedaulatan Negara Kesatuan Republik Indonesia. Sejalan dengan hal tersebut kewajiban membela negara telah diatur dalam UUD 1945 pasal 30 ayat (1) ditegaskan bahwa "tiap-tiap warga negara berhak dan wajib ikut serta dalam usaha pertahanan dan keamanan negara". Sedangkan konsep bela negara diatur dalam UUD 1945 pasal 27 ayat (3) bahwa "setiap warga negara berhak dan wajib ikut serta dalam upaya pembelaan negara".

Penjelasan pasal tersebut dapat dipahami bahwa keikutsertaan warga negara dalam membela negara merupakan suatu hak dan kewajiban. Setiap warga negara dituntut untuk mempunyai kesadaran dan kesediaan berbakti pada negara serta berkorban membela negara dari pengaruh luar negeri. Penanaman sikap bela negara dapat terwujud apabila adanya peran keluarga dalam menanamkan sikap tersebut pada setiap warga negara (remaja).

Kenyataannya, ada berbagai masalah dalam pelaksanaan menanamkan sikap bela negara yakni remaja kurang memiliki sikap bela negara terbukti dengan tidak memakai atribut sekolah lengkap, tidak hafal lagu nasional, kurang responsif 
CIVICS EDUCATION AND SOCIAL SCIENSE JOURNAL(CESSJ)

Volume 2 Nomor 1 Bulan Juni 2020

mengikuti upacara hari besar nasional, kurangnya menyukai produk dalam negeri dan lain-lain. Fakta yang terjadi adalah keluarga dan remaja belum memahami konsep bela negara bahwa sesungguhnya bela negara bukan hanya dilakukan oleh Tentara Nasional Indonesia saja, namun bela negara menjadi hak dan kewajiban setiap warga negara dalam usaha pertahanan dan keamanan negara. Sehingga, masalah ini memerlukan suatu peran keluarga dalam menanamkan sikap bela negara pada remaja untuk mewujudkan landasan dan nilai-nilai bela negara.

\section{KAJIAN PUSTAKA}

\section{Pengertian Keluarga}

Keluarga memegang peranan utama dalam membentuk anak mempunyai sikap hormat kepada semua orang termasuk anggota keluarganya. Sehingga keluarga merupakan wadah yang sangat penting bagi pembentukan karakter anak, serta sumber kasih sayang dan perlindungan baginya. Lestari, S (2012: 22) mengatakan keluarga merupakan tempat yang penting bagi perkembangan anak secara fisik, emosi, spiritual, dan sosial. Karena keluarga merupakan sumber bagi kasih sayang, perlindungan, dan identitas bagi anggotanya.

Sebagai sistem sosial terkecil, keluarga memiliki pengaruh luar biasa dalam hal menanamkan sikap bela negara pada remaja. Keluarga merupakan lingkungan pertama dan utama bagi perkembangan individu, karena sejak kecil anak tumbuh dan berkembang dalam lingkungan keluarga. Oleh sebab itulah peranan keluarga bersifat sentral dan sangat besar bagi penanaman sikap bela negara pada remaja.

\section{Fungsi Keluarga}

Menurut Bens dalam Lestari, S (2012: 22) keluarga memiliki lima fungsi dasar, yaitu: a) Fungsi Reproduksi. Keluarga memiliki tugas untuk mempertahankan populasi yang ada di dalam masyarakat. b) Fungsi Sosialisasi/edukasi. Keluarga menjadi sarana untuk transmisi nilai, keyakinan, sikap, pengetahuan, keterampilan, dan teknik dari generasi sebelumnya ke generasi yang lebih muda. c) Fungsi Penugasan peran sosial. Keluarga memberikan identitas pada para angotanya seperti ras, etnik, religi, sosial ekonomi, dan peran gender. d) Fungsi dukungan ekonomi. Keluarga menyediakan tempat berlindung, makanan dan jaminan kehidupan. e) Fungsi dukungan emosi/pemeliharaan. Keluarga 
CIVICS EDUCATION AND SOCIAL SCIENSE JOURNAL(CESSJ)

Volume 2 Nomor 1 Bulan Juni 2020

memberikan pengalaman interaksi sosial yang pertama bagi anak. Interaksi yang terjadi bersifat mendalam, mengasuh, dan berdaya tahan sehingga memberikan rasa aman pada anak.

\section{Pendidikan Karakter Bela Negara}

Menurut kamus umum bahasa Indonesia, karakter diartikan sebagai tabiat; watak; sifat-sifat kejiwaan, akhlak atau budi pekerti yang membedakan seseorang dengan yang lain. Karakter terbentuk dari kebiasaan, dimana orangtua bisa mempengaruhi baik atau buruk pembentukan kebiasaan anak-anak. Kebiasaan itu dapat terbentuk dari bayi sampai masa remaja. Salah satu pembentukan karakter adalah sikap bela negara. Setiap warga negara patut mencintai dan membela negaranya. Hal ini sesuai dengan konstitusional dalam pasal 27 ayat (3) UndangUndang Dasar 1945, yang berbunyi "Setiap warga negara berhak dan wajib ikut serta dalam upaya pembelaan Negara". Oleh sebab itu setiap warga negara dewasa yang sehat jasmani dan rohani untuk dapat melaksanakan hak dan kewajiban tersebut yang dilandasi dengan integritas yang tinggi dan memiliki jatidiri sebagai bangsa Indonesia.

Bela negara dapat diartikan sebagai kewajiban yang harus dimiliki oleh setiap warga negara. Bela negara merupakan sikap dan perilaku warga negara dalam yang dijiwai kecintaannya terhadap NKRI yang berdasarkan pancasila dan UUD 1945 dalam menjalin kelangsungan hidup bangsa dan negara yang utuh. Menurut Subagyo (2015: 59) menjelaskan bahwa bela negara menurut para ahli, diantaranya: bela negara adalah suatu pemikiran, perilaku dan tindakan yang dilakukan oleh setiap warga negara untuk membela bangsa dan negaranya; sikap warga negara yang berupaya mempertahankan negara ketika menghadapi berbagai ancaman yang mengganggu kepentingan negaranya; bela negara merupakan wujud nyata dari nasionalisme, patriotisme dan cinta tanah air yang tercermin dalam setiap warga negara sehingga mutlak dimiliki oleh warga negara agar negaranya menjadi kuat. Oleh sebab itu, bela negara merupakan perilaku yang harus melekat pada setiap individu.

Hal ini sesuai dengan pendapatnya Sutarman (2011: 78) menyatakan bahwa pembelaan negara atau bela negara adalah tekad, sikap, dan tindakan warga negara yang teratur, menyeluruh, terpadu, berkelanjutan yang dilandasi oleh kecintaan pada tanah air, kesadaran berbangsa dan berbegara Indonesia, keyakinan 
CIVICS EDUCATION AND SOCIAL SCIENSE JOURNAL(CESSJ)

Volume 2 Nomor 1 Bulan Juni 2020

akan kesaktian pancasila sebagai ideologi negara, dan kerelaan berkorban guna meniadakan setiap ancaman baik dari luar maupun dari dalam negeri yang membahayakan kedaulatan dan kemerdekaan negara, kesatuan dan persatuan bangsa, keutuhan wilayah dan yurudiksi nasional, serta nilai-nilai Pancasila dan UUD 1945.

\section{Fungsi dan Tujuan Bela Negara}

Berdasarkan Setjen Wantannas (2018) bahwa tujuan bela negara, diantaranya: 1) Mempertahankan kelangsungan hidup bangsa dan negara, 2) Melestarikan budaya, 3) Menjalankan nilai-nilai pancasila dan UUD 1945, 4) Berbuat yang terbaik bagi bangsa dan negara, dan 5) Menjaga identitas dan integritas bangsa/ negara. Sedangkan fungsi bela negara, diantaranya: 1) Mempertahankan Negara dari berbagai ancaman; 2) Menjaga keutuhan wilayah negara; 3) Merupakan kewajiban setiap warga negara, dan 4) Merupakan panggilan sejarah.

\section{Perlunya Pendidikan Bela Negara}

Kesadaran bela negara bukanlah sesuatu yang tumbuh dengan sendirinya dalam diri setiap warga negara, namun perlu upaya-upaya sadar dan terencana secara matang untuk menanamkan dalam diri warga negara. Menurut Edi (2019: 14) landasan dan nilai-nilai bela negara sebagai berikut, yaitu : (a) cinta terhadap tanah air, (b) sadar berbangsa dan bernegara, (c) tentu yakin akan Pancasila sebagai ideologi negara dan (d) rela berkorban untuk bangsa dan negara Indonesia serta (e) memiliki kemampuan awal bela negara. Kelima landasan dan nilai-nilai bela negara tersebut memerlukan peran keluarga dalam menanamkan sikap bela negara kepada remaja. Tugas membela negara merupakan suatu kewajiban dan keharusan setiap warga negara termasuk remaja.

Kelima nilai dasar dalam pembentukan karakter bela negara tersebut dijabarkan dalam pengembangan nilai-nilai sebagai berikut:

1. Cinta Tanah air.

a. Mengenal dan memahami wilayah Nusantara dengan baik.

b. Mencintai dan melestarikan lingkungan hidup.

c. Menjaga nama baik dan mengharumkan Tanah air Indonesia.

2. Sadar berbangsa dan bernegara. 
CIVICS EDUCATION AND SOCIAL SCIENSE JOURNAL(CESSJ)

Volume 2 Nomor 1 Bulan Juni 2020

a. Menumbuhkan rasa kesatuan dan persatuan bangsa dan negara Indonesia.

b. Mencintai Budaya Bangsa \& Produksi Dalam Negeri.

c. Menumbuhkan rasa memiliki jiwa besar dan patriotisme.

d. Memiliki kesadaran atas tanggung jawab sebagai warga negara Indonesia.

3. Yakin pada Pancasila Sebagai Ideologi Negara.

a. Keyakinan dan kesadaran akan kebenaran Pancasila sebagai ideologi negara.

b. Pancasila merupakan sumber hukum dan sekaligus sebagai kerangka acuan Negara Kesatuan Republik Indonesia

c. Nilai-nilai Pancasila juga dapat digunakan dalam penyelesaian konflik serta mematahkan setiap ancaman, tantangan, hambatan serta gangguan terhadap keutuhan bangsa masih dapat kita atasi bersama berdasarkan kaidah demokrasi Pancasila yang menjunjung tinggi sifat kekeluargaan dan gotong royong.

4. Rela berkorban untuk bangsa dan negara.

a. Mendahulukan kepentingan umum daripada kepentingan pribadi/ golongan.

b. Mencurahkan perhatian keikhlasan tenaga dan pikiran untuk menyelesaikan tugas, hak dan kewajiban tanpa pamrih.

c. Rela berkorban waktu, harta, raga maupun jiwa untuk kepentingan nusa dan bangsa.

5. Memiliki kemampuan awal bela negara.

a. Kemampuan psikis (Mental) yaitu setiap warga negara dituntut untuk memiliki sikap dan perilaku disiplin, ulet bekerja keras mentaati segala perundang-undangan, percaya akan kemampuan diri sendiri, tahan uji dan pantang menyerah dalam menghadapi kesulitan hidup.

b. Kemampuan fisik. Memiliki kemampuan awal bela negara dalam bentuk kemampuan fisik (jasmani) yang sehat, tangkas, postur tubuh yang proporsional.

\section{Pengertian Remaja}

Menurut Hurlock (2003: 206) Istilah adolescence atau remaja berasal dari kata latin (adolescene), kata bendanya adolescentia yang berarti remaja yang berarti "tumbuh" atau "tumbuh menjadi dewasa" bangsa orang-orang zaman purbakala memandang masa puber dan masa remaja tidak berbeda dengan periode-periode 
CIVICS EDUCATION AND SOCIAL SCIENSE JOURNAL(CESSJ)

Volume 2 Nomor 1 Bulan Juni 2020

lain dalam rentang kehidupan anak dianggap sudah dewasa apabila sudah mampu mengadakan reproduksi. Hal senada diungkapkan oleh Santrock (2007: 20) bahwa remaja (adolescence) diartikan sebagai masa perkembangan transisi antara masa anak dan masa dewasa yang mencakup perubahan biologis, kognitif, dan sosialemosional.

Batasan usia masa remaja menurut Hurlock (2003: 206), Awal masa remaja berlangsung dari mulai umur 13-16 tahun atau 17 tahun, dan akhir masa remaja bermula dari usia 16 atau 17 tahun sampai 18 tahun, yaitu usia matang secara hukum. Dengan demikian akhir masa remaja merupakan periode yang sangat singkat. Menurut Santrock (2002: 23) bahwa awal masa remaja dimulai pada usia 10-12 tahun, dan berakir pada usia 21-22 tahun.

\section{METODE}

Penelitian ini menggunakan pendekatan kualitatif dengan metode deskriptif kualittaif. Penelitian dilakukan di Desa Planggu, Kecamatan Trucuk, Kabupaten Klaten. Subjek penelitian terdiri dari keluarga dan remaja Desa Planggu, Kecamatan Trucuk, Kabupaten Klaten. Hasil pengumpulan data diperoleh melalui observasi, teknik wawancara, dan dokumentasi yang dapat dianalisis menggunakan model analisis data kualitatif yang terdiri dari reduksi data, penyajian data, dan verifikasi data (Miles dan Huberman, 1992). Data yang diperoleh kemudian divalidasi menggunakan teknik triangulasi sumber dan teknik pengumpulan data.

\section{HASIL PENELITIAN DAN PEMBAHASAN}

\section{Hasil Penelitian}

\section{Sikap Bela Negara Remaja}

Sikap bela negara merupakan sikap yang harus dimiliki oleh setiap warga negara. Sebagai warga negara kita harus mempunyai sikap cintai tanah air melalui bentuk menjaga pertahanan dan keamanan negara Indonesia. Hal ini tidak hanya dilakukan oleh Tentara Nasional Indonesia, namun menjaga pertahanan dan keamanan negara menjadi tugas kita bersama.

Hasil penelitian menunjukkan bahwa remaja kurang mempunyai sikap bela negara. Hasil penelitian tersebut yaitu 1) keluarga dan remaja kurang menyukai produk dalam negeri, 2) tidak hafalnya lagu nasional, 3) remaja tidak memakai atribut lengkap saat mengikuti upacara, 4) seringnya remaja bolos sekolah, 5) belum 
CIVICS EDUCATION AND SOCIAL SCIENSE JOURNAL(CESSJ)

Volume 2 Nomor 1 Bulan Juni 2020

melestarikan budaya belajar dengan rajin. Sikap-sikap inilah jelas terlihat bahwa remaja-remaja zaman sekarang perlu adanya peningkatan pendidikan karakter yang lebih mendalam. Berbagai tindakan yang dilakukan cenderung berdampak negatif ke masa depan remaja. Kurangnya sikap bela negara ini perlu adanya evaluasi dari berbagai pihak, baik keluarga maupun sekolah. Remaja juga harus mempunyai sikap bela negara baik di lingkungan rumah ataupun di sekolah. Wujud dari sikap bela negara yang harus dimiliki remaja yaitu cinta tanah air, rela berkorban, sadar berbangsa dan bernegara, mengimplementasikan nilai-nilai Pancasila dalam kehidupan sehari-hari, dan memiliki kemampuan awal bela negara.

\section{Peran Keluarga dalam Menanamkan Sikap Bela Negara pada Remaja}

Peran keluarga sangat diperlukan untuk menumbuhkan karakter pada remaja. Keluarga merupakan orang terdekat yang dapat membentuk anak mempunyai karakter yang baik atau buruk. Pembentukan tersebut dapat terealisasi dengan kebiasaan-kebiasaan yang dilakukan pada kehidupan sehari-hari. Keluarga dapat mengontrol karakter anak apabila dianggap menyimpang dari nilai-nilai yang diajarkannya. Suatu perhatian khusus kepada remaja sangat dibutuhkan, karena anak menganggap bahwa keluarga merupakan orang terpenting. Hal ini dapat ditunjukkan keluarga melalui perhatian, kasih sayang, perlindungan dan identitas bagi anggotanya.

Hasil penelitian menunjukkan bahwa peran keluarga dalam menanamkan sikap bela negara pada remaja di Desa Planggu, Kecamatan Trucuk, Kabupaten Klaten masih kurang. Peran yang dilakukan keluarga kurang optimal disebabkan oleh orangtua dan keluarga lain sibuk dengan pekerjaannya. Fakta menunjukkan bahwa remaja merasa tidak diperhatikan oleh keluarga sehingga ia dapat melakukan tindakan yang tidak diketahui oleh orang tua dan keluarga lain. Implikasi yang ditumbulkan yaitu kurangnya sikap karakter khususnya sikap bela negara.

Peran keluarga sebenarnya sudah dilakukan secara optimal, namun aktualisasi perlu dilakukan secara lebih mendalam dan berkelanjutan. Perlunya peran keluarga kepada remaja tidak hanya diaktualisakan melalui pendidikan dan pengajaran bela negara setiap hari, namun perlu adanya contoh nyata, sehingga remaja dapat menerapkan sikap bela negara dari keluarga secara baik dan benar. 
CIVICS EDUCATION AND SOCIAL SCIENSE JOURNAL(CESSJ)

Volume 2 Nomor 1 Bulan Juni 2020

\section{Pembahasan}

Sikap bela negara perlu ditanam sejak dini pada diri individu setiap remaja. Penanaman itu tidak mudah, tidak hanya melalui pendidikan dan pengajaran. Penanaman sikap bela negara juga harus ada korelasi antara pihak sekolah dan pihak keluarga. Pihak yang berperan pertama dan utama tentu harus dari keluarga baik orangtua, kakak, adik dan keluarga lain. Menanamkan bela negara tentu harus berpatokan pada nilai-nilai Pancasila dan nilai-nilai bela negara. Menurut Edi, J (2019: 14) landasan dan nilai-nilai bela negara sebagai berikut, yaitu : (a) cinta terhadap tanah air, (b) sadar berbangsa dan bernegara, (c) tentu yakin akan Pancasila sebagai ideologi negara dan (d) rela berkorban untuk bangsa dan negara Indonesia serta (e) memiliki kemampuan awal bela negara. Langkah konkrit dalam mengaktualisasikan lima unsur tersebut, setiap warga negara memiliki hak dan kewajiban untuk melaksanakannya. Nilai-nilai ini tentu berkembang secara bersinergi guna menciptakan suatu sikap bela negara secara maksimal. Membela negara harus didorong atas kesadaran dan rasa tanggung jawab untuk ikut bela negara dalam rangka mewujudkan cita-cita kemerdekaan berdasarkan UndangUndang Dasar 1945.

Penyelenggaraan bela negara didasarkan pada kesadaran atas hak dan kewajiban warga negara serta keyakinan pada kekuatan sendiri. Bela negara sebagai suatu sikap dan tindakan remaja yang bersifat teratur, menyeluruh terpadu, dan terarah yang dilandasi kecintaannya pada tanah air serta kesadaran dalam berbangsa dan bernegara Indonesia. Jika seseorang memiliki rasa cinta terhadap tanah air yang mendalam, maka secara langsung akan memiliki tekad membangun dan menjaga negara dari pengaruh negara lain. Hal ini sesuai dengan pendapatnya Winarno (2012: 182) menyatakan bela negara adalah upaya setiap warga negara untuk mempertahankan NKRI terhadap ancaman baik dari dalam maupun dari dalam negeri.

Upaya bela negara, selain sebagai kewajiban dasar manusia, juga merupakan kehormatan bagi setiap warga negara yang dilaksanakan dengan penuh kesadaran, tanggung jawab, dan rela berkorban dalam pengabdian kepada negara dan bangsa. Hal ini sesuai dengan Keputusan Sekretaris Jenderal Dewan Ketahanan Nasional Nomor 170 Tahun 2018 bahwa pada dasarnya merupakan: 
CIVICS EDUCATION AND SOCIAL SCIENSE JOURNAL(CESSJ)

Volume 2 Nomor 1 Bulan Juni 2020

1. Jiwa kecintaan kepada Negara Kesatuan Republik Indonesia yang berdasarkan Pancasila dan Undang-Undang Dasar 1945 dalam menjamin kelangsungan hidup bangsa dan negara;

2. Kewajiban dasar manusia; dan

3. Kehormatan bagi setiap warga negara yang dilaksanakan dengan penuh kesadaran, tanggung jawab dan rela berkorban dalam pengabdian kepada negara dan bangsa.

Implementasi sikap bela negara pada remaja dapat diwujudkan dengan sikap rajin belajar, dan kepatuhan dan ketaatan pada aturan sekolah dan keluarga. Hal ini sebagai perwujudan rasa cinta tanah air dan bela negara. Adanya ketaatan pada aturan yang berlaku di sekolah dan keluarga akan menciptakan keamanan dan ketentraman bagi lingkungan.

Nilai, keyakinan, dan aturan kedisiplinan yang ada dalam ideologi Pancasila harus ditanamkan kepada anak sejak dini. Tentunya, penanaman tersebut sejalan dengan perkembangan kognitif anak dan dilaksanakan secara terus-menerus dengan konsisten. Dengan demikian, nilai-nilai yang diajarkan akan berbuah menjadi perilaku dan kebiasaan dalam kehidupan mereka seharihari. Salah satu cita-cita bela negara adalah perlindungan anak. Menurut Republika (2015: 9), maka melalui bela negara diharapkan akan terbangun generasi yang memiliki karakter disiplin, optimisme, kerja sama, dan kepemimpinan yang sudah barang tentu menjamin kelangsungan hidup bangsa dan negara kita.

Kemampuan berbela negara harus dilakukan sedini mungkin melalui pihak keluarga. Keluarga mempunyai peran besar untuk memperkuat sikap atau karakter anak (remaja). Sehingga menurut Ryamizard Ryacudu (2015) bahwa melalui bela negara akan terbangun karakter disiplin, optimisme, kerjasama dan kepemimpinan guna turut menjamin kelangsungan hidup bangsa dan negara.

Keluarga merupakan lingkungan tumbuh dan berkembangnya anak sejak dini hingga mereka dewasa. Melalui pendidikan dalam keluargalah karakter seorang dapat dibentuk. Maka, peran utama dalam menanamkan sikap bela negara adalah keluarga. Melalui kebiasaan-kebiasaan atau tindakan yang dilakukan secara terus-menerus dan konsisten maaka akan terbentuk suatu karakter yang melekat pada anak remaja. Keluarga juga mempunyai peran dalam memberikan kasih sayang, perlindungan, dan perhatian pada remaja. Keluarga perlu memberikan perhatian khusus pada anak, misalnya mengontrol kelengkapan atribut seragam, 
CIVICS EDUCATION AND SOCIAL SCIENSE JOURNAL(CESSJ)

Volume 2 Nomor 1 Bulan Juni 2020

mengawasi kedisiplinan masuk atau bolos sekolah, mengajak anak mencintai segala macam produk dalam negeri, mengajari kedisiplinan dalam belajar, dan membiasakan anak menolong orang yang kesusahan atau tertimpa musibah.

Sikap-sikap positif bela negara tersebut harus dikembangkan secara terusmenerus dan konsisten, sehingga pertahanan dan keamanan negara dapat terjaga dengan baik. Sikap positif inilah akan menjadi kebiasaan-kebiasaan yang dapat berguna bagi lingkungan baik masyarakat, bangsa dan negaranya. Permasalahan inilah mendorong adanya peningkatan peran keluarga dalam menanamkan sikap bela negara pada anak khususnya remaja.

\section{SIMPULAN}

Keluarga merupakan sumber pendidikan karakter yang paling pertama dan utama. Salah satu karakter yang perlu ditanamkan sejak dini oleh remaja yaitu sikap bela negara. Bela negara merupakan pemikiran, perilaku dan tindakan yang dilakukan oleh setiap warga negara untuk membela bangsa dan negaranya. Hal ini kesadaran bela negara bukan tumbuh dengan sendirinya, namun diperlukan suatu upaya-upaya sadar dan terencana guna melekatkan sikap bela negara pada setiap diri remaja. Peran keluarga dalam menanamkan sikap bela negara masih kurang ditandai dengan: 1) keluarga dan remaja kurang menyukai produk dalam negeri, 2) tidak hafalnya lagu nasional, 3) remaja tidak memakai atribut lengkap saat mengikuti upacara, 4) seringnya remaja bolos sekolah, 5) belum melestarikan budaya belajar dengan rajin.

Setiap warga negara termasuk remaja perlu adanya sikap membela negara. Hal ini bertujuan untuk menjaga keutuhan Negara Kesatuan Republik Indonesia. Dalam hal menjaga keutuhan negara tidak hanya memerlukan Tentara Nasional Indonesia, namun diperlukan kesadaran berbela negara dari setiap individu warga negara.

Pada dasarnya keluarga telah berperan secara optimal dalam berupaya menumbuhkan kesadaran sikap bela negara pada diri remaja. Hanya saja dalam aktualisasinya perlu upaya dan kesadaran secara mendalam dan berkelanjutan. Sebab penanaman sikap bela negara harus dilakukan dengan berkelanjutan, sehingga sikap tersebut dapat melekat pada setiap diri remaja. Oleh sebab itu, keluarga mempunyai peran yang sangat penting dalam menanamkan sikap bela negara pada remaja di Desa Planggu, Kecamatan Trucuk, Kabupaten Klaten. 
CIVICS EDUCATION AND SOCIAL SCIENSE JOURNAL(CESSJ)

Volume 2 Nomor 1 Bulan Juni 2020

\section{REFERENSI}

Edi, J. (2019). Modul Pendidikan Karakter Bela Negara dalam Pembelajaran. Palembang: Noerfikri.

Hurlock, Elizabeth B. (2003). Psikologi Perkembangan. Jakarta: Erlangga.

Jhon W. Santrock. (2002). Adolescence Perkembangan Remaja. Jakarta: Erlangga.

Keputusan Sekretaris Jenderal Dewan Ketahanan Nasional Nomor 170 Tahun 2018 tentang Buku Modul Utama Pembinaan Bela Negara.

Lestari, Sri. (2012). Psikologi Keluarga Penanaman Nilai dan Penanganan Konflik dalam Keluarga. Jakarta: PT Kencana Prenada Media Group.

Miles, M. \& Huberman, A. M. (1992). Analisis Data Kualitatif. Terjemahan oleh Tjetjep Rohandi Rohidi. Jakarta: UI Press.

Republika. (2015). Bela Negera di Usia Dini. Jakarta: Republika.

Ryamizard Ryacudu, 2015, Tanamkan Nilai Kebangsaan dan Cinta Tanah Air Sejak Dini, Kementerian Pertahanan dan Kemeterian Pemberdayaan Perempuan Dan Perlindungan Anak Republik Indonesia. http://www.kemenpppa.go.id/index.php/page/read/29/1 62/pressrelease-tanamkan-nilai-kebangsaan-dan-cintatanah-air-sejak-dini, diakes pada tanggal 5 Desember 2017.

Santrock, John W. (2007). Perkembangan Anak Jilid 1 Edisi kesebelas. Jakarta: PT Erlangga.

Setjen Wantannas. (2018). Bela Negara: Pengertian, Unsur, Fungsi, Tujuan dan Manfaat Bela Negara. https://www.wantannas.go.id/2018/10/19/belanegara-pengertian-unsur-fungsi-tujuan-dan-manfaat-bela-negara/.

Subagyo, Agus. (2015). Bela Negara (Peluang dan Tantangan di Era Globalisasi). Yogyakarta: Graha Ilmu.

Sutarman. Persepsi dan Pengertian Pembelaan Negara berdasarkan UUD 1945 (Amandemen). Jurnal Magistra No.75 Th.IXIXIII.

Winarno. (2012). Paradigma Baru Pendidikan Kewarganegaraan. Jakarta: PT Bumi Aksara. 